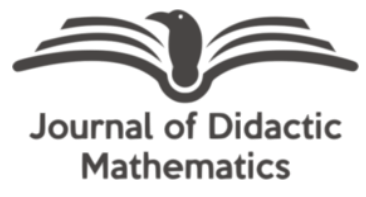

\title{
Meningkatkan resiliensi matematis mahasiswa pada mata kuliah matematika dasar melalui pendekatan differentiated instruction
}

\section{Ade Evi Fatimah*}

STKIP Al Maksum, Langkat, Sumatera Utara, Indonesia, 20814

\author{
Azrina Purba \\ STKIP Al Maksum, Langkat, Sumatera Utara, Indonesia, 20814 \\ *Corresponding Author: adeevifatimah@stkipalmaksum.ac.id
}

\begin{abstract}
This study is a Classroom Action Research with a qualitative descriptive method, which aims to increase students' mathematical resilience when using the Different Instruction approach. The subjects of this study were 40 first-semester students of class B of Informatics Engineering and Computer Education STKIP Al Maksum Langkat. The object of this research is the students' mathematical resilience ability through the Different Instruction approach in the basic mathematics subject matter of functions. This research procedure refers to four stages, namely planning, acting, observing, and reflecting. This research was conducted in two cycles, the research was based on the criteria that reached $85 \%$ for students who produced a minimum result of $65 \%$. The instrument used in this study was a non-test question in the form of a mathematical resilience scale given at the beginning and end of the lesson. Based on the results of the study, it can be ignored that the Instruction Differentiation approach can improve the mathematical resilience of the first semester B grade students of the PTIK study program, by grouping students based on learning styles more effective in increasing students' mathematical resilience in applying the Instruction Differentiation approach.
\end{abstract}

Historis Artikel:

Diterima: 14 Maret 2021

Direvisi: 22 Maret 2021

Disetujui: 16 April 2021

\section{Keywords:}

mathematical resilience; differentiated instruction approach; action research

Sitasi: Fatimah, A. E., \& Purba, A. (2021). Meningkatkan resiliensi matematis mahasiswa pada mata kuliah matematika dasar melalui pendekatan differentiated instruction. Journal of Didactic Mathematics, 2(1), 42-49. Doi: $10.34007 /$ jdm.v2i1.617

\section{PENDAHULUAN}

Perkembangan ilmu pengetahuan di era globalisasi ini sangat pesat, sehingga dibutuhkan SDM tangguh dan percaya diri yang mampu berpikir secara logis, analitis, dan sistematis dalam menghadapi kondisi persaingan global di masyarakat. Sikap dan cara berpikir ini dapat dikembangkan melalui pembelajaran matematika di setiap jenjang pendidikan. Oleh karena itu, STKIP Al Maksum, sebagai salah satu tempat mencetak SDM, mewajibkan semua peserta didik di setiap program studi mempelajari mata kuliah Matematika, tidak terkecuali program studi Pendidikan Teknik Informatika dan Komputer (PTIK). Setelah mengampu mata kuliah ini mahasiswa diharapkan mampu berpikir secara sistematis dan lebih tangguh untuk mengatasi kesulitan dan memecahkan berbagai permasalahan. Bernard (2015) menyatakan bahwa mata pelajaran matematika perlu diberikan kepada seluruh peserta didik untuk membekalinya dengan kemampuan berpikir logis, sistematis, analitis, kritis, dan kreatif, serta kemampuan bekerja sama. Maharani (2018) tujuan pembelajaran matematika salah satunya adalah untuk mengasah cara berpikir dan bernalar peserta didik dalam menarik kesimpulan serta mampu mengungkapkan pendapatnya dengan percaya diri dan kejujuran yang timbul dari peserta didik untuk memecahkan masalah yang dihadapi. Selanjutnya, Fatimah et al. (2020) menyatakan bahwa pembelajaran matematika bertujuan untuk membentuk pola pikir mahasiswa yang logis dan sistematis serta 
Meningkatkan resiliensi matematis mahasiswa pada mata kuliah matematika dasar...

memiliki kejujuran dan rasa percaya diri dalam mengungkapkan pendapatnya agar mampu mengatasi kesulitan dan memecahkan berbagai permasalahan.

Iman (2019) menyatakan bahwa matematika memang bukanlah mata pelajaran yang mudah untuk dipelajari. Sehingga dalam proses pembelajarannya akan ditemui beberapa kesulitan dan hambatan yang dapat menurunkan semangat nahasiswa dalam belajar. Sejalan dengan Iman, menurut Fatimah et al. (2020), fakta di STKIP Al Maksum Langkat, masih banyak mahasiswa yang mengalami kesulitan ketika belajar mata kuliah Matematika, khususnya materi Fungsi. Jika soal berbeda dengan contoh yang diberikan maka mahasiswa langsung bingung dan tidak bisa mengerjakan soal karena selain kurangnya pemahaman terhadap masalah yang diberikan, mahasiswa juga kurang memiliki rasa percaya diri, kejujuran, ketangguhan, dan ketekunan dalam belajar matematika. Sikap-sikap inilah yang menggambarkan resiliensi matematis mahasiswa.

Grotberg (Zanthy, 2018) menyatakan bahwa resiliensi adalah kemampuan seseorang untuk menilai, mengatasi, dan meningkatkan diri ataupun mengubah dirinya dari keterpurukan atau kesengsaraan dalam hidup, karena setiap orang itu pasti mengalami kesulitan ataupun sebuah masalah dan tidak ada seseorang yang hidup di dunia tanpa suatu masalah ataupun kesulitan. Hendriana et al. (Chusna et al., 2019) menyatakan resiliensi merupakan kemampuan seseorang dalam meraih keberhasilan dengan cara beradaptasi pada semua kondisi meskipun berada dalam keadaan penuh tantangan. Sedangkan resiliensi matematis menurut Sugandi (2017) adalah sikap berkualitas dalam pembelajaran matematika yang meliputi percaya diri melalui usaha keras akan keberhasilan, memperlihatkan ketekunan dalam menemukan kesulitan, mempunyai keinginan untuk berdiskusi, mencerminkan, dan melakukan penelitian. Selanjutnya menurut Sumarmo (2018) resiliensi matematis memuat sikap tekun atau tangguh dalam menghadapi kesulitan, bekerja atau belajar kolaboratif dengan teman sebaya, memiliki keterampilan berbahasa untuk menyatakan pemahaman matematik, dan menguasai teori belajar matematika. Kemudian Johnston-Wilder (2010) menyatakan bahwa mahasiswa yang memiliki resiliensi matematis akan bertahan saat menghadapi kesulitan, akan berhasil secara kolaboratif dengan teman sebayanya, akan memiliki keterampilan bahasa yang dibutuhkan untuk mengekspresikan pemahaman dan akan memiliki teori pembelajaran yang berkembang. Sama halnya menurut Goodall (2015) mahasiswa dengan kemampuan resiliensi matematis memiliki keyakinan bahwa kemampuan mereka dalam bidang matematika akan tumbuh. Dengan demikian dapat disimpulkan bahwa mahasiswa yang memiliki resiliensi matematis adalah mahasiswa yang mampu beradaptasi dalam setiap kondisi, memiliki rasa sadar akan kemampuannya, yakin, dan percaya diri bahwa mereka juga memahami apa yang orang lain pahami dan mampu menghadapi dan menyelesaikan permasalahan dan hambatan dalam pembelajaran matematika, serta mampu memberikan solusi yang tepat hingga akhirnya mereka akan sukses.

Berdasarkan pernyataan di atas, maka perlu untuk meningkatkan resiliensi matematis dalam diri mahasiswa. Salah satu cara untuk meningkatkan resiliensi matematis adalah dengan menggunakan pendekatan pembelajaran yang inovatif, yaitu pendekatan Differentiated Instruction (DI). Kasus yang sering ditemukan di kampus adalah setiap kelas berisi campuran heterogen mahasiswa dengan tingkat kemampuan, kebutuhan, dan latar belakang yang berbeda. Oleh karena itu, dosen harus mampu membedakan instruksi pembelajaran dan menyediakan kesempatan belajar di kelas agar semua mahasiswa terpenuhi kebutuhannya. Tomlinson (2000) menyatakan bahwa Differentiated Instruction (DI) adalah suatu pembelajaran yang memaksimalkan potensi setiap peserta didik dengan memperhatikan kebutuhannya. Heacox (2002) menyatakan Differentiated Instruction (DI) secara khusus merespon kemajuan belajar mahasiswa secara berkelanjutan; apa yang telah mereka ketahui dan apa yang ingin mereka pelajari sehingga di dalam pembelajaran DI, setiap mahasiswa mendapatkan pembelajaran yang sesuai dengan kebutuhan mereka. Arviana (2014) menyatakan bahwa di dalam DI, pembelajaran dirancang sedemikian rupa sehingga mahasiswa dapat menikmati pembelajaran namun tujuan pembelajaran juga tercapai. Fatimah \& Purba (2018) juga menyatakan bahwa setiap mahasiswa pasti memiliki karakter yang berbeda-beda. Untuk menghadapi perbedaan karakter tersebut, digunakan pendekatan DI dalam pembelajaran 
matematika yang berdasarkan kepada pembelajaran yang bervariasi dan disesuaikan dengan kebutuhan masing-masing mahasiswa, agar dapat memaksimalkan potensi dan keberhasilan setiap mahasiswa dalam lingkup pembelajaran matematika. Jika pembelajaran dibuat sesuai kebutuhan mahasiswa maka mahasiswa akan lebih semangat, tekun, dan percaya diri dalam belajar. Dengan kata lain mahasiswa akan memiliki resiliensi matematis dalam dirinya.

Good (Ditasona, 2017) Ada beberapa cara dalam membuat DI diantaranya adalah yang dengan menggunakan (1) Teacher Based Method, yaitu berdasarkan kurikulum, isi, proses, dan produk. (2) Student Based Method, yaitu berdasarkan kesiapan belajar, minat dan gaya belajar siswa. Selanjutnya menurut Tomlinson (1999) berdasarkan karakter mahasiswa, DI dapat dilakukan dengan tiga hal : (1) kesiapan belajar, jika tugas belajar yang diberikan sesuai dengan kemampuan siswa, (2) minat, jika tugas belajar yang diberikan dapat merangsang rasa ingin tahu, dan gairah belajar siswa, (3) gaya belajar, jika tugas belajar dapat mendorong siswa untuk bekerja dengan cara yang disukainya. Selanjutnya Defitriani (2018) menyatakan bahwa pembelajaran DI dilakukan dengan kerja kelompok karena lebih efektif. Pengelompokkan akan memudahkan mahasiswa untuk berinteraksi dengan teman-temannya dalam memahami dan menyelesaikan masalah matematika. Pengelompokkan yang diterapkan adalah pengelompokkan fleksibel, yang dinamis, berubah sesuai dengan konten, proyek, dan terus menerus dievaluasi.

Berdasarkan hasil penelitian terdahulu yang dilakukan oleh Arviana (2014) dan Fatimah (2016) diperoleh bahwa kemampuan pemecahan masalah matematika siswa berkembang setelah diterapkan pembelajaran pendekatan Differentiated Instruction. Peningkatan kemampuan pemecahan masalah matematis lebih tinggi dibanding siswa yang memperoleh pembelajaran konvensional. Selain itu, dari penelitian Defitriani (2018) juga diperoleh hasil penelitian bahwa implementasi pembelajaran dengan pendekatan Differentiated Instruction akan lebih efektif untuk meningkatkan kemampuan koneksi matematis ketika menggunakan pengelompokkan berdasarkan minat siswa (individu, berpasangan, atau diskusi kelompok). Hal ini berdasarkan learning profile siswa yang berbeda dan kenyamanan siswa dalam proses diskusi, sehingga aktivitas diskusi memfasilitasi siswa untuk melakukan koneksi. Selanjutnya dari penelitian Harmini (2019) diperoleh hasil penelitian bahwa terdapat perbedaan yang signifikan antara kemampuan pemahaman konsep matematika mahasiswa sebelum penggunaan modul pembelajaran berbasis Differentiated Instruction dengan sesudah penggunaan modul pembelajaran berbasis Differentiated Instruction. Berdasarkan beberapa hasil penelitian tentang penerapan pendekatan Differentiated Instruction tersebut dan sadar akan pentingnya resiliensi matematis di dalam diri mahasiswa, maka penulis ingin menerapkan pendekatan Differentiated Instruction untuk meningkatkan resiliensi matematis mahasiswa pada mata kuliah matematika dasar dalam materi fungsi.

\section{METODE}

Penelitian ini merupakan penelitian tindakan kelas (PTK) dengan menggunakan model siklus spiral yang dikembangkan Kemmis (Mulhamah, 2016). Penelitian ini bertujuan untuk menggambarkan bagaimana peningkatan resiliensi matematis mahasiswa setelah melaksanakan pembelajaran melalui pendekatan Differentiated Instruction (DI) pada mata kuliah matematika dasar materi fungsi. Metode yang digunakan dalam penelitian ini adalah kualitatif deskriptif, Manalu (2020) menyatakan bahwa tujuan dari penelitian deskriprif adalah untuk menerangkan sifat, gejala, dan keadaan secara tepat dari suatu individu ataupun kelompok. Sedangkan metode kualitatif ialah prosedur penelitian yang menghasilan data deskriptif dari orang-orang atau perilaku yang bisa diamati. Subjek penelitian ini adalah mahasiswa semester I kelas B prodi Pendidikan Teknik Informatika dan Komputer STKIP Al Maksum Langkat tahun akademik 2020-2021 dengan jumlah mahasiswa 40 orang, sedangkan objek dalam penelitian ini resiliensi matematis mahasiswa setelah menerima pembelajaran dengan pendekatan DI. 
Meningkatkan resiliensi matematis mahasiswa pada mata kuliah matematika dasar...

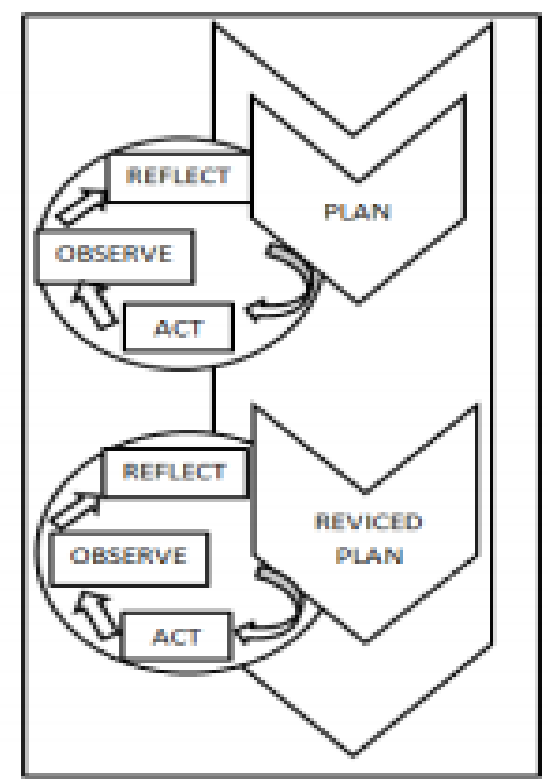

Gambar 1. Model Penelitian Tindakan Kemmis

Mulhamah (2016) menyatakan bahwa setiap siklus terdiri dari perencanaan (planning), tindakan (action), pengamatan (observation), dan refleksi (reflection). Keempat fase dalam penelitian tindakan kelas digambarkan dengan sebuah spiral PTK seperti ditunjukkan dalam Gambar 1.

PTK ini terdiri dari dua siklus, karena pada siklus II kriteria keberhasilan sudah terpenuhi. Adapun kriteria keberhasilan yang digunakan untuk menghentikan atau melanjutkan siklus dalam penelitian ini dilihat dari aspek peningkatan resiliensi matematis mahasiswa yang memperoleh pembelajaran matematika dengan pendekatan Differentiated Instruction (DI). Jika kriteria keberhasilan telah mencapai $85 \%$ untuk mahasiswa yang memperoleh persentase penilaian hasil minimal 65\%, maka siklus akan dihentikan. Data yang dikumpulkan pada setiap pelaksanaan siklus penelitian dianalisis secara deskriptif dengan menggunakan teknik persentase untuk melihat kecenderungan yang terjadi dalam kegiatan pembelajaran. Sebelum melaksanakan pembelajaran, terlebih dahulu membagi mahasiswa ke dalam kelompok belajar sesuai dengan gaya belajar masing-masing (berdasarkan pendekatan Differentiated Instruction). Instrumen yang digunakan dalam penelitian ini adalah non tes berupa angket resiliensi matematis yang terdiri dari 25 pernyataan serta dilengkapi dengan 4 pilihan jawaban, yaitu Sering sekali (SS), Sering (S), Jarang (J) dan Jarang Sekali (JS). Angket resiliensi matematis diukur dengan menggunakan skala likert. Sugiyono (2018) mengatakan skala likert digunakan untuk mengukur sikap, pendapat, dan persepsi seseorang atau sekelompok orang tentang fenomena sosial. Kemudian hasil angket resiliensi matematis subjek dikelompokan menjadi tiga berdasarkan rangking seperti Tabel 1 di bawah ini.

Tabel 1. Kategori Pengelompokan Hasil Angket Resiliensi Matematis Mahasiswa

\begin{tabular}{cc}
\hline Skor & Kategori \\
$X<\bar{x}-S D$ & Resiliensi Rendah \\
$\bar{x}-S D \leq X<\bar{x}+S D$ & Resiliensi Sedang \\
$X \geq \bar{x}+S D$ & Resiliensi Tinggi \\
\hline
\end{tabular}

Sumber: Arikunto (2018)

\section{HASIL DAN PEMBAHASAN}

Tujuan utama penelitian ini adalah untuk menggambarkan bagaimana peningkatan resiliensi matematis mahasiswa setelah melaksanakan pembelajaran melalui pendekatan Differentiated Instruction (DI) pada mata kuliah matematika dasar materi fungsi. Berikut disajikan hasil penelitian berupa gambaran secara umum kemampuan resiliensi matematis mahasiswa. 
Hasil Penelitian Siklus I

Pembelajaran yang dibuat menggunakan pendekatan Differentiated Instruction (DI) pada Siklus I adalah dengan mengelompokkan mahasiswa berdasarkan kepada kesiapan belajar. Soal-soal yang diberikan disesuaikan dengan kemampuan masing-masing kelompok. Namun berdasarkan hasil observasi pada tindakan Siklus I menunjukkan bahwa pembelajaran dengan menggunakan pendekatan Differentiated Instruction (DI) masih merupakan hal yang baru bagi mahasiswa, oleh karena itu masih banyak mahasiswa yang merasa canggung. Hal ini terlihat dari mahasiswa belum aktif dan masih menyesuaikan diri selama proses pembelajaran berlangsung. Mahasiswa yang kesiapan belajarnya belum matang masih merasa belum percaya diri dan tidak semangat, masih terlihat belum mau berusaha dan mudah menyerah dalam menjawab soal-soal yang diberikan. Adapun hasil resiliensi matematis mahasiswa pada Siklus I dapat dilihat pada Tabel 2 berikut:

Tabel 2. Deskripsi Level Resiliensi Matematis Mahasiswa Siklus I

\begin{tabular}{cccc}
\hline Level & Banyak Mahasiswa & Persentase Jumlah Mahasiswa (\%) & Rata-rata Skor Resiliensi Matematis \\
\hline Tinggi & 16 & 40 & $73,5(65 \%)$ \\
Sedang & 10 & 25 & \\
Rendah & 14 & 35 & \\
\hline$\Sigma$ & 40 & $100 \%$ & \\
\hline
\end{tabular}

Table 2 menunjukkan peningkatan resiliensi matematis mahasiswa yang mengampu mata kuliah matematika dasar pada materi fungsi setelah diterapkan pendekatan DI selama proses pembelajaran berlangsung. Jumlah mahasiswa yang telah mencapai ketuntasan sebanyak 26 orang $(65 \%)$ dengan peningkatan resiliensi matematis mahasiswa mengalami kenaikan dengan rata-rata kelas mencapai 73,5. Karena resiliensi matematis mahasiswa belum mencapai target minimal 85\% dari mahasiswa yang mengikuti tes pada proses pembelajaran, maka perlu perbaikan program pengajaran sehingga tercapai target minimal penelitian. Karena masih ditemukan beberapa kekurangan dalam proses pembelajaran selama pelaksanaan Siklus I, maka perlu dilakukan perbaikan tindakan. Oleh karena itu peneliti akan melanjutkan ke Siklus II.

\section{Hasil Penelitian Siklus II}

Adapun hasil resiliensi matematis mahasiswa pada Siklus II dapat dilihat pada Tabel 3 berikut:

Tabel 3. Deskripsi Level Resiliensi Matematis Mahasiswa Siklus II

\begin{tabular}{cccc}
\hline Level & Banyak Mahasiswa & Persentase Jumlah Mahasiswa (\%) & Rata-rata Skor Resiliensi Matematis \\
\hline Tinggi & 23 & 57,5 & \\
Sedang & 12 & 30 & $81,8(87,5 \%)$ \\
Rendah & 5 & 12,5 & \\
\hline$\Sigma$ & 40 & $100 \%$ & \\
\hline
\end{tabular}

Resiliensi matematis mahasiswa pada Siklus II mengalami peningkatan yang cukup baik dari Siklus I. Banyak mahasiswa yang mencapai ketuntasan pada Siklus II yaitu mencapai 35 orang dengan persentase $87,5 \%$. Peningkatan resiliensi matematis mahasiswa sudah mencapai target penelitian yaitu minimal $85 \%$ mahasiswa yang memperoleh persentase penilaian hasil minimal $65 \%$ dari siswa yang mengikuti tes pada proses pembelajaran.

Pembelajaran yang dibuat dengan menggunakan pendekatan Differentiated Instruction (DI) pada Siklus II ini adalah dengan mengelompokkan mahasiswa berdasarkan kepada gaya belajar. Soal-soal yang diberikan dapat mendorong mahasiswa untuk bekerja dengan cara yang disukainya. Berdasarkan hasil observasi pada Siklus II, maka diperoleh temuan penelitian bahwa melalui pendekatan DI dengan mengelompokkan mahasiswa berdasarkan gaya belajar lebih efektif dalam meningkatkan resiliensi matematis mahasiswa. Pembagian kelompok berdasarkan gaya belajar memberikan hasil yang maksimal, membuat mahasiswa lebih semangat dan percaya diri dalam 
Meningkatkan resiliensi matematis mahasiswa pada mata kuliah matematika dasar...

belajar. Karena gaya belajar mahasiswa dalam satu kelompok sama, maka mereka dapat bekerjasama dengan baik, mereka menjadi sekelompok mahasiswa yang tangguh dan gigih dalam menyelesaikan permasalahan yang diberikan, dan mampu mengekspresikan pemahaman mereka melalui gaya belajar yang disukainya. Hal ini sejalan dengan pandangan Tomlinson (1995) mengemukakan bahwa DI dapat dilakukan dengan tiga hal, diantaranya (1) kesiapan belajar, yaitu jika tugas belajar yang diberikan sesuai dengan kemampuan peserta didik, (2) minat, yaitu jika tugas belajar dapat merangsang rasa ingin tahu dan gairah belajar peserta didik, dan (3) profil belajar, yaitu jika tugas belajar dapat mendorong peserta didik untuk bekerja dengan cara yang disukainya.

Penggunaan pendekatan Differentiated Instruction (DI) dalam upaya meningkatkan resiliensi matematis mahasiswa pada siklus I sudah menunjukkan peningkatan rata-rata kelas mencapai 73,5. Terdapat 26 mahasiswa dari 40 mahasiswa (65\%) telah mencapai kriteria keberhasilan (minimal 65) sedangkan $14(35 \%)$ mahasiswa lainnya belum mencapai kriteria keberhasilan. Namun karena belum mencapai kriteria keberhasilan minimal 85\%, maka dilanjutkan ke siklus II. Setelah siklus II dilakukan terjadi peningkatan resiliensi matematis mahasiswa. Dari pemberian angket pada siklus II ini diperoleh bahwa resiliensi matematis, mahasiswa mengalami peningkatan ketuntasan belajar sejauh $22,5 \%$, yakni dari $65 \%$ menjadi $87,5 \%$. Nilai rata-rata kelas yang diperoleh adalah 81,8 . Hal ini menunjukkan bahwa pendekatan DI efektif dalam meningkatkan resiliensi matematis mahasiswa. Hasil penelitian yang dilakukan Iskandar (2016) menemukan bahwa penerapan pendekatan DI memberikan kontribusi yang baik terhadap perkembangan kemampuan pemecahan masalah matematis mahasiswa. Penelitian Simanjuntak \& Listiani (2020) juga menjelaskan bahwa penerapan DI dapat meningkatkan pemahaman konsep matematika siswa.

Adanya peningkatan dari Siklus I ke Siklus II tidak terlepas dari upaya-upaya yang dilakukan peneliti, yaitu mengelompokkan mahasiswa berdasarkan kesiapan belajar pada Siklus I dan berdasarkan gaya belajar pada Siklus II. Dengan cara ini, mahasiswa lebih aktif, tekun, semangat, dan percaya diri, serta mampu berkolaborasi atau bekerjasama yang baik dengan rekan sejawatnya. Kesulitan dalam menyelesaikan masalah yang diberikan mampu mereka selesaikan bersama-sama karena memiliki kesiapan dan gaya belajar yang sama dalam masing-masing kelompok. Sejalan dengan Defitriani (2018) yang menyatakan bahwa pembelajaran DI dilakukan dengan kerja kelompok karena lebih efektif. Pengelompokkan akan memudahkan mahasiswa untuk berinteraksi dengan teman-temannya dalam memahami dan menyelesaikan masalah matematika. Berdasarkan learning profile siswa yang berbeda dan kenyamanan siswa dalam proses diskusi, sehingga aktivitas diskusi memfasilitasi siswa untuk melakukan koneksi.

Oleh karena itu, adanya kesamaan kesiapan dan gaya belajar dalam satu kelompok belajar, mahasiswa mampu saling membantu dan mendukung satu sama lain. Pembelajaran melalui pendekatan Differentiated Instruction (DI) ini telah berhasil meningkatkan resiliensi matematis mahasiswa semester I kelas B prodi Pendidikan Teknik Informatika dan Komputer STKIP Al Maksum yang mengampu mata kuliah matematika dasar pada materi fungsi.

\section{KESIMPULAN}

Kesimpulan dari temuan penelitian yang diperoleh adalah resiliensi matematis mahasiswa meningkat baik dilihat dari nilai individu maupun klasikal dari siklus I ke siklus II. Hal ini merujuk pada kesimpulan bahwa penerapan pembelajaran melalui pendekatan Differentiated Instruction (DI) dapat meningkatkan resiliensi matematis mahasiswa semester I kelas B prodi Pendidikan Teknik Informatika dan Komputer STKIP Al Maksum pada mata kuliah matematika dasar. Penerapan pembelajaran melalui pendekatan Differentiated Instruction (DI) pada penelitian ini hanya berfokus untuk meninjau resiliensi matematis mahasiswa pada mata kuliah matematika dasar materi fungsi. Untuk memaksimalkan hasil/temuan penelitiam, peneliti selanjutnya diharapkan dapat mempertimbangkan kesiapan, minat dan profil belajar subjek dalam penerapan pendekatan Differentiated Instruction (DI), disamping itu juga agar dapat mengimplementasikan pendekatan DI dalam meninjau kemampuan matematis yang lainnya. 


\section{DAFTAR PUSTAKA}

Arikunto, S. (2018). Dasar-Dasar Evaluasi Pendidikan Edisi 3. Jakarta: PT Bumi Aksara

Arviana, N. N. dan Siswono, T. Y. E. (2014). Penerapan Pendekatan Differentiated Instruction untuk Mengembangkan Kemampuan Pemecahan Masalah Matematika Siswa Kelas VIII SMP pada Materi Kubus dan Balok. MATHEdenusa Jurnal Ilmiah Pendidikan Matematika, 3(3), 150-157

Bernard, M. (2015). Meningkatkan Kemampuan Komunikasi dan Penalaran serta Disposisi Matematik Siswa SMK dengan Pendekatan Kontekstual melalui Game Adobe Flash CS 4.0. Jurnal Infinity, 4(2), 197-222

Chusna, A. C., Rochmad., \& Prasetyo, A. P. B. (2019). Mathematical Resilience Siswa pada Pembelajaran Team Assisted Individualization dalam Upaya Meningkatkan Kemampuan Penalaran Matematika. Prosiding Seminar Nasional Pascasarjana (Prosnampas), 2(1), 157-162

Defitriani, E. (2018). Mengembangkan Kemampuan Koneksi Matematis Siswa melalui Pendekatan Differentiated Instruction. AN ARGY A: Jurnal Ilmiah Pendidikan Matematika, 1(2), $72-76$

Ditasona, C. (2017). Penerapan Pendekatan Differentiated Instruction dalam Peningkatan Kemampuan Penalaran Matematis Siswa SMA. Jurnal EduMatSains, 2(1), 43-54

Fatimah, A. E. (2016). Peningkatan Kemampuan Pemecahan Masalah Matematis dan Kemandirian Belajar Siswa SMK Negeri 1 Percut Sei Tuan melalui Pendekatan Differentiated Instruction. MES (Journal of Mathematics Education and Science), 2(1), 11-23

Fatimah, A. E. \& Purba, A. (2018). Pengembangan Lembar Aktivitas Siswa (LAS) menggunakan Pendekatan Differentiated Instruction untuk Meningkatkan Kemampuan Pemecahan Masalah Matematis Siswa SMK. MES (Journal of Mathematics Education and Science), 4(1), 1-9

Fatimah, A. E., Purba, A., \& Siregar, Y. A. (2020). Hubungan resiliensi matematis terhadap kemampuan pemecahan masalah matematis mahasiswa pada mata kuliah Matematika dasar. Journal of Didactic Mathematics, 1(3), 151-157. https://doi.org/10.34007/jdm.v1i3.470

Goodall, J., \& Johnston-Wilder, S. (2015). Overcoming Mathematical Helplessness and Developing Mathematical Resilience in Parents: An Illustrative Case Study. Creative Education, 6, 526-535

Harmini, T. (2019). Efektivitas Penggunaan Modul Berbasis Differentiated Instruction untuk Meningkatkan Kemampuan Pemahaman Konsep Matematika Mahasiswa. Jurnal Didaktike Matematika, 6(2), 136-148

Heacox, D. (2002). Differentiating Instruction in The Regular Classroom. USA: Free Spirit Publishing; Iman, S. A., \& Firmansyah, D. (2019). Pengaruh Kemampuan Resiliensi Matematis terhadap Hasil Belajar Matematika. Prosiding Seminar Nasional Matematika dan Pendidikan Matematika Sesiomadika. 356-360

Iskandar, R. S. F. (2016). Penerapan Pendekatan Differentiated Instruction untuk Mengembangkan Kemampuan Pemecahan Masalah Matematis Mahasiswa. Alphamath: Journal of Mathematics Education, 2(2), 47-53. https://doi.org/10.30595/alphamath.v2i2.1231

Johnston-Wilder, Sue and Lee, Clare (2010). Developing mathematical resilience. In: BERA Annual Conference 2010, 1-4 Sep 2010, University of Warwick

Maharani, S., \& Bernard, M. (2018). Analisis Hubungan Resiliensi Matematik terhadap Kemampuan Pemecahan Masalah Siswa pada Materi Lingkaran. JPMI - Jurnal Pembelajaran Matematika Inovatif, 1(5), 819-826

Manalu, A. C. S. dan Afrilianto, M. (2020). Peningkatan Kemampuan Pemahaman Matematis Siswa Kelas VIII SMP Pasundan 9 Bandung pada Materi Persamaan Garis Lurus dengan menggunakan Pendekatan Konstektual. JPMI (Jurnal Pembelajaran Matematika Inovatif), 3(4), 363-370. Doi: 10.22460/jpmi.v3i4

Mulhamah., \& Putrawangsa, S. (2016). Penerapan Pembelajaran Kontekstual dalam Meningkatkan Kemampuan Pemecahan Masalah Matematika. Jurnal Pendidikan Matematika, 10(1), 58-80

Simanjuntak, S., \& Listiani, T. (2020). Penerapan Differentiated Instruction dalam Meningkatkan 
Meningkatkan resiliensi matematis mahasiswa pada mata kuliah matematika dasar...

Pemahaman Konsep Matematika Siswa Kelas 2 SD. Scholaria: Jurnal Pendidikan Dan Kebudayaan, 10(2), 134-141. https://doi.org/10.24246/j.js.2020.v10.i2.p134-141

Sugandi, A. I. (2017). Meningkatkan Kemampuan Berpikir Kreatif dan Resiliensi Matematis Siswa SMP melalui Pendekatan Generatif. Jurnal Perspektif Pendidikan, 11(2), 67-77

Tomlinson, C. A. 1995. Diciding to differentiated Instruction in the middle school: One school's journey. Gifted Children Quaterly, 39(2), 77-114

Tomlinson, C.A. (1999). The Differentiated Classroom: Responding to the Needs of All Learners. Alexandria: Association for Supervision and Curriculum Development

Tomlinson, C.A. (2000). What is Differentiated Instruction? Alexandria: Association for Supervision and Curriculum Development

Sumarmo, U. (2018). Hardskill dan Softskill Matematika Serta Kearifan Lokal dalam Pembelajaran Matematika. Proceeding National Seminar of Mathematics Education Unswagati Cirebon. Cirebon

Sugiyono. (2018). Metode Penelitian Pendidikan Pendekatan Kuantitaitif, Kualitatif, dan R $\odot D$. Bandung: Alfabeta

Zanthy, L. S. (2018). Kontribusi Resiliensi Matematis terhadap Kemampuan Akademik Mahasiswa pada Mata Kuliah statistika Matematika. Jurnal Mosharafa, 7(1), 85-94 